\title{
The Effects of Crises on Volatility Spillovers between Borsa Istanbul Sector Indexes ${ }^{\mathrm{i}}$
}

\author{
Melik Kamışlı $^{1}$, Serap Kamışııı, ${ }^{2, *}$, Güven Sevil ${ }^{3}$ \\ ${ }^{1}$ Department of Banking and Insurance, Bozuyuk Vocational School, Bilecik Seyh Edebali University, Turkey \\ ${ }^{2}$ Department of Banking and Finance, School of Applied Sciences, Bilecik Seyh Edebali University, Turkey \\ ${ }^{3}$ Department of Accounting and Finance, Faculty of Open Education, Bilecik Seyh Edebali University, Turkey
}

Copyright $\bigcirc 2016$ by authors, all rights reserved. Authors agree that this article remains permanently open access under the terms of the Creative Commons Attribution License 4.0 International License

\begin{abstract}
The crises that occurred in the last century showed that crises can change financial and economic relationships between the regions and countries. But, especially 1998 Asian Crisis put a spotlight on volatility spillovers and contagion effects. After the crisis there has been made studies that analyze contagion effects and changing spillovers between the markets due to the crisis. The volatility spillovers provide information to investors to be used in investment decisions. Especially risk averse investors use this information in diversification and portfolio allocation decisions. But some investors want to invest in specific sectors. So, it will be useful to analyze the relations between sectors. In this context, the purpose of this study is to analyze the volatility spillovers between industrial, services and financial sectors of Turkish stock market Borsa Istanbul, on the basis of 2008 Global Crisis and Greece Debt Crisis. For this purpose we use Hafner and Herwartz causality in variance test (2006). The findings reveal that there are reciprocal volatility spillovers between industrial and financial sectors and unidirectional spillover from services to industrial sector before the 2008 Global Crisis. But there is no spillover between the index returns after the Global Crisis indicating that crises change the volatility linkages between sector index returns. It is also determined there are volatility spillovers from industrial sector to services and financial sectors and from services to financial sector.
\end{abstract}

Keywords 2008 Global Crisis, Greece Debt Crisis, Volatility Spillover, Sector Indexes, Causality in Variance Test

JEL Codes: G11, G01, C01

\section{Introduction}

Volatility is defined as the variation in the return of a security or market for a specific period of time [1]. For another description volatility is the tendency of assets price or market to fluctuate either up or down. Volatility is considered as an indicator of risk of the security or market and increased volatility is perceived as a rise in the financial risk that is thought to affect the value of asset and wealth of the investor [2]. For this reason it is very important to analyze the volatility of the security or market that is thought to be investing in. But the last studies showed that volatility of a variable not only depends on its own dynamics, the volatility of a variable can affect the volatility of another variable. In other words, there can be relationships between the volatilities of assets and markets.

Due to the financial liberalization, markets are getting integrated day by day and a shock that occurred in a market is transmitted to another market by financial channels. Especially, after a shock, event or crisis, volatility of a financial variable can spill over to another financial variable because of the connections between the variables. This phenomenon is called volatility spillover and it states a stable dynamic relation between the variables. According to another definition, volatility spillover is the increase in volatility of a variable because of the increase in volatility of other variable with a time lag [3].

Volatility spillovers may be seen as the risk transfer from one variable to another one. But it can present useful information if they can be analyzed properly. In other words, if there is a relationship between two variables, then one can be used in forecast of the other one, so that one can make a forecast for the future movements of a variable by observing the movements of the other variables. Analyzing volatility spillovers can present information to the investors that can be used in portfolio construction, portfolio management and diversification. But it is so hard to determine the volatility spillovers between the variables because they can be affected from too many factors and especially from the crises. Different types of crises can change the degree and direction of the volatility spillovers.

The crisis that occurred in Asia in 1998 put a spotlight on 
volatility spillovers and contagion effects. After the crisis there has been made studies that analyze the volatility spillovers and their importance on portfolio and risk management processes. To invest in different stock markets give investors the opportunity of gaining benefits from international diversification. But volatility spillovers between stock markets decrease the benefits of international diversification by increasing non-systematic risk of the portfolio [4].

Another way to gain benefit from diversification is to invest in specific sectors. Some of the sectors may not be effected from events occurred in the economy and there may not be volatility spillovers between some of the sectors. But in order to invest in sectors, volatility spillovers between the sectors should also be analyzed properly and the effects of the crises on the spillovers should be determined. In this context, the purpose of this study is to determine the direction of volatility spillovers between BIST sector index returns that are thought to change because of 2008 Global Crisis and 2009 Greek Debt Crisis. By analyzing volatility spillovers, some information will be gained that investors who create their portfolio based on BIST sectors can use in portfolio management decisions.

\section{Literature}

There exists a vast literature on modelling volatility spillovers over the past decade. The approaches that are used in these studies can be grouped as cointegration analyses, multivariate generalized autoregressive conditional heteroskedasticity (MGARCH) models, causality in variance tests, regime-switching and stochastic volatility models. Hammoudeh et al. (2009), Moore (2011) and Dania and Spillan (2013) determined the direction of volatility spillovers between markets of different countries. Hassan and Malik (2007), Athanasios and Kanellos (2010) and O and Ali (2014) analyzed volatility spillovers on the basis of sectors and indexes.

It is proved with many studies that financial crises have effects on volatility spillovers. Financial crises occurs due to the adverse selection and moral hazard problems [5] and they are grouped as currency crises, banking crises, debt crises and systemic crises based on the source of problem. These crises affect the relations between the economic and financial variables and of course the volatility spillovers. Especially after the Asian Crisis researchers have focused on the effects of crises on volatility spillovers. Khalid and Kawai (2003), Yang (2005) and Cho and Parhizgari (2008) determined the effects of Asian Crisis. Dimitriou and Simos (2013), Wang (2014), Luchtenberg and Vu (2015) and Dungey and Gajurel (2014) identified the effects of 2008 Global Crisis on volatility spillovers between stock markets. Kenourgios et al. (2011), Junior and Franca (2012), Kenourgios and Padhi (2012) and Bekiros (2014) investigated changing volatility spillovers due to more than one crisis that occur in the analysis period.
There are also studies in the literature that investigate the effects of crises on volatility spillovers between sectors. Chan-Lau and lvaschenko, (2002), Nikkinen et al. (2013), Ranjeeni, (2014) and Syriopoulos et al. (2015) analyzed the changing volatility spillovers between sector indexes due to the different types of crises.

Causality in variance tests that are introduced by Cheung and $\mathrm{Ng}$ (1996), Hong (2001) and Hafner and Herwartz (2006) are used frequently in order to determine the direction of volatility spillovers. Alaganar and Bahr (2003), Neaime (2006) and Köseoğlu and Çevik (2013) used Cheung and Ng and Hong causality in variance tests to investigate volatility spillovers between different financial markets. But there are limited studies that analyze volatility spillovers with Hafner-Herwartz causality in variance test. Some of them are made by Görmüş (2012), Nazlığlu et al. (2013) and Nazlıoğlu et al. (2015).

There are studies in the literature that examine the volatility spillovers between Turkish financial markets. Taşdemir and Aslan, (2009), Korkmaz and Çevik, (2009), Okur and Çevik, (2013) and Adıgüzel et al. (2013) used causality in variance tests in their studies. In the light of studies in the literature, it is thought that it will be useful for investors to analyze changing volatility spillovers between Turkish stock market sector indexes within the context of financial crises.

\section{Methodology and Data}

In the study, causality in variance test which is developed by Hafner and Herwartz is used to determine the volatility spillovers between BIST sector index returns. Hafner and Herwartz causality in variance test gives the opportunity of analyzing the relations between variables in terms of volatility. Also, this methodology is useful in determining the direction of volatility spillovers and investigating causality relations especially for high frequency data.

Cheung and Ng (1996) and Hong (2001) tests which are used in volatility spillover analysis depend on standardized cross correlation functions (CCF) gained from univariate GARCH models. But Hafner and Herwartz (2006) indicated in their study that cross correlation function that depends on Portmanteau test is insufficient for small and medium size samples when volatility processes are leptokurtic. Also they showed that the results of approach based on CCF are sensitive to the orders of leads and lags that cause questions about the robustness of findings. Hafner and Herwartz proposed as an alternative model to mentioned models is as follows;

$$
\begin{gathered}
H_{0}: \operatorname{Var}\left(\varepsilon_{i t} \mid \mathcal{F}_{t-1}^{(j)}\right)=\operatorname{Var}\left(\varepsilon_{i t} \mid \mathcal{F}_{t-1}\right) \quad J=1, \ldots, N, i \neq j \\
\text { Here; } F_{t}^{j}=F_{t} \backslash \sigma\left(\varepsilon_{J t}, t<t\right. \\
\varepsilon_{i t} \text { error terms of GARCH model. }
\end{gathered}
$$

The model that will be used to test null hypothesis is as 
follows;

$$
\varepsilon_{i t}=\xi_{i t} \sqrt{\sigma_{i t}^{2} g_{t}}, g_{t}=1+z_{j t}^{\prime} \pi, z_{j t}=\left(\varepsilon_{j t-1}^{2}, \sigma_{j t-1}^{2}\right)^{\prime}
$$

$$
\sigma_{i t}^{2}=\omega_{i}+\alpha_{i} \varepsilon_{i, t-1}^{2}+\beta_{i} \sigma_{i, t-1}^{2} \text { conditional variance, }
$$

$\xi_{i t}$, standardized errors of GARCH model.

In order to test null hypothesis, $\pi$ coefficient that is in the 4 equation is tested if it is significantly different from zero or not. $H_{0}: \pi=0$, states that there is no causality in variance and $H_{1}: \pi \neq 0$ states that there is causality in variance. Gauss logarithmic likelihood function value of $\varepsilon_{i t}$;

$$
x_{i t}\left(\xi_{i t}^{2}-1\right) / 2 \text {, }
$$

Here;

$$
x_{i t}=\sigma_{i t}^{-2}\left(\partial \sigma_{i t}^{2} / \partial \theta_{i}\right), \quad \theta_{i}=\left(\omega_{i}, \alpha_{i}, \beta_{i}\right)^{\prime}
$$

Hafner and Herwartz (2006) proposed the following Lagrange multiplier (LM) test to determine the volatility spillover between two series;

$$
\lambda_{L M}=\frac{1}{4 T}\left(\sum_{t=1}^{T}\left(\xi_{i t}^{2}-1\right) z_{j t}^{\prime}\right) V\left(\theta_{i}\right)^{-1}\left(\sum_{t=1}^{T}\left(\xi_{i t}^{2}-1\right) z_{j t}\right)
$$

Here;

$$
\begin{array}{r}
V\left(\theta_{i}\right)= \\
\frac{K}{4 T}\left(\sum_{t=1}^{T} z_{j t} z_{j t}^{\prime}-\sum_{t=1}^{T} z_{j t} x_{i t}^{\prime}\left(\sum_{t=1}^{T} x_{i t} x_{i t}^{\prime}\right)^{-1} \sum_{t=1}^{T} x_{i t} z_{i t}^{\prime}\right) \\
K=\frac{1}{T} \sum_{t=1}^{T}\left(\xi_{i t}^{2}-1\right)^{2}
\end{array}
$$

Asymptotic distribution of $\lambda_{L M}$ depends on the number of misspecification indicators in $Z_{j t}$. If there are two misspecification indicators therefore test will have asymptotic chi-square distribution.

Within the scope of study, we used returns calculated from daily closing values of BIST Industrial (XUSIN), Services (XUHIZ) and Financial (XUMAL) sector indexes. Index returns were calculated as follows;

$$
R_{t}=\ln \left(\frac{F_{t}}{F_{t-1}}\right)
$$

$F_{t}$, states price index at day $\mathrm{t}$.

Data set is limited with 3.544 daily observations between 2001 and 2015. Analysis periods are determined according to the crises. The first period lasts until the collapse of Lehman Brothers, in other words beginning of 2008 Global Crisis (08.14.2008). The second period lasts from 2008 Global Crisis to beginning of Greek Debt Crisis (03.11.2009). The third period lasts from Greek Debt Crisis to 06.18.2015.

In the analyses, 3.544 daily data of sector indexes were used between 02.20.2001- 24.03.2015 and data were gained from BIST database. Periods that are determined based on the crises are as follows;
1. Period: 02.20.2001 - 08.14.2008 observations)
2. Period: 09.14.2008 - 03.11.2009 observations)
3. Period: 04.11.2009 - 06.18.2015 observations)

$(1864$

\section{Empirical Results}

Descriptive statistics of sector index returns are given as of periods in Table 1. When descriptive statistics table is analyzed, it is seen that for all of the periods high kurtosis values indicates that big shocks are probable. In other words, for all period's sector index returns move away from normal distribution with high skewness and kurtosis values.

Studies in which financial time series are used, testing stationarity is very important in order to avoid from spurious regression problem [6]. In this context, stationarity of sector index return series were tested with Augmented Dickey Fuller (ADF) unit root test and results are given in Table 2. It is seen from Table 2 that series have no unit root. In other words, series are stationary.

Table 1. Descriptive Statistics of Index Return Series as of Periods

\begin{tabular}{|c|c|c|c|c|c|c|c|c|c|}
\hline & \multicolumn{3}{|c|}{ XUSIN } & \multicolumn{3}{c|}{ XUHIZ } & \multicolumn{3}{c|}{ XUMAL } \\
\hline & $1^{\text {st }} \mathrm{P}$. & $2^{\text {nd }} \mathrm{P}$. & $3^{\text {rd }} \mathrm{P}$. & $1^{\text {st }} \mathrm{P}$. & $2^{\text {nd }} \mathrm{P}$. & $3^{\text {rd }} \mathrm{P}$. & $1^{\text {st }} \mathrm{P}$. & $2^{\text {nd }} \mathrm{P}$. & $3^{\text {rd }} \mathrm{P}$. \\
\hline Mean & 0.001 & 0.001 & 0.001 & 0.001 & 0.001 & 0.001 & 0.001 & 0.001 & 0.001 \\
\hline Median & 0.001 & 0.003 & 0.001 & 0.001 & 0.001 & 0.001 & 0.001 & 0.002 & 0.001 \\
\hline Max. & 0.124 & 0.08 & 0.07 & 0.118 & 0.12 & 0.062 & 0.14 & 0.141 & 0.077 \\
\hline Min. & -0.18 & -0.08 & -0.12 & -0.193 & -0.07 & -0.09 & -0.21 & -0.11 & -0.11 \\
\hline Std. Dev. & 0.02 & 0.021 & 0.013 & 0.022 & 0.02 & 0.013 & 0.026 & 0.031 & 0.018 \\
\hline Skew. & -0.39 & -0.23 & -1.25 & -0.161 & 0.397 & -0.659 & -0.152 & 0.089 & -0.388 \\
\hline Kurtosis & 10.39 & 6.11 & 13.42 & 9.382 & 5.791 & 7.885 & 7.731 & 6.035 & 5.473 \\
\hline
\end{tabular}


Table 2. ADF Statistics of Index Return

\begin{tabular}{|c|c|c|c|c|}
\hline & & None & Intercept & $\begin{array}{l}\text { Trend and } \\
\text { Intercept }\end{array}$ \\
\hline \multirow{3}{*}{ 1. period } & XUSIN & $-43.89 *$ & $-43.99 *$ & $-44.02 *$ \\
\hline & XUHIZ & $-43.43 *$ & $-43.51 *$ & $-43.50 *$ \\
\hline & XUMAL & $-42.97 *$ & $-43.01 *$ & $-43.01 *$ \\
\hline \multirow{3}{*}{ 2. period } & XUSIN & $-13.73 *$ & $-11.26^{*}$ & $-11.47^{*}$ \\
\hline & XUHIZ & $-15.86^{*}$ & $-15.88^{*}$ & $-12.09 *$ \\
\hline & XUMAL & $-14.95 *$ & $-14.95^{*}$ & $-15.03 *$ \\
\hline \multirow{3}{*}{ 3. period } & XUSIN & $-12.45^{*}$ & $-12.62 *$ & $-12.64 *$ \\
\hline & XUHIZ & $-37.85^{*}$ & $-37.88^{*}$ & $-37.86^{*}$ \\
\hline & XUMAL & $-19.10 *$ & $-19.11 *$ & $-19.11 *$ \\
\hline
\end{tabular}

$* \% 1 * * \% 5 * * * \% 10$ significance level

Before determining the volatility spillovers, unconditional correlations between sector indexes were calculated for each period. Unconditional correlations that are given in Table 3 show the direction and size of relations between sector indexes. Correlation coefficient takes a value between -1 and +1 . When Table 3 is analyzed, it is seen that there are positive directional relations between sector indexes for all periods.

Table 3. Unconditional Correlations between Sector Index Returns as of Periods

\begin{tabular}{|c|c|c|c|}
\hline & 1.period & 2. period & 3. period \\
\hline XUSIN_XUHIZ & 0.802 & 0.547 & 0.512 \\
\hline XUSIN_XUMAL & 0.881 & 0.610 & 0.593 \\
\hline XUHIZ_XUMAL & 0.810 & 0.536 & 0.532 \\
\hline
\end{tabular}

Unconditional correlation coefficients do not give information about the volatility spillovers and the direction of spillovers. So, in the next step of the study, we used Hafner and Herwartz causality in variance test in order to determine the direction of volatility spillovers between sector indexes on the basis of crises, Results are given in Table 4.

According to causality in variance test results, there is a bidirectional volatility spillover between industrial and financial sector indexes and there is a unidirectional volatility spillover from services sector index to financial sector index. There is no volatility spillover between sector indexes in the second period. But, in the third period, in other words after the Greek Debt Crisis, there is a unidirectional volatility spillover from industrial sector index to financial and services sector indexes and from services sector index to financial sector index. Findings indicate that crises changed the direction of volatility spillovers between the sector indexes.

The volatility spillover that is determined in the first period can be explained by foreign investments that increased after "high interest rate-low exchange rate" policy. In the second period, the absence of volatility spillover can be explained by international capital flows that changed its direction quickly due to the 2008 Global Crisis and Greek Debt Crisis. As for third period, the events that affected the export size and tourism sector of Turkey can be aligned as; deepened European Debt Crisis, Arab Spring and crises of Ukraine and Russia. In this context, the change of volatility spillovers between industrial and services sector indexes in the third period can be explained by international events.

Table 4. Causality in Variance Analysis Results as of Periods

\begin{tabular}{|c|c|c|c|c|c|}
\hline \multicolumn{2}{|c|}{1 period } & \multicolumn{2}{c|}{ 2. period } & period \\
\hline XUSIN $\neq>$ XUHIZ & 0.63 & XUSIN $\neq>$ XUHIZ & 0.14 & XUSIN $=>$ XUHIZ \\
\hline XUSIN $=>$ XUMAL & 0.06 & XUSIN $\neq>$ XUMAL & 0.32 & XUSIN $=>$ XUMAL & XUHIZ $\neq>$ XUSIN \\
\hline XUHIZ $\neq>$ XUSIN & 0.11 & XUHIZ $\neq>$ XUSIN & 0.88 & 0.76 \\
\hline XUHIZ $=>$ XUMAL & 0.07 & XUHIZ $\neq>$ XUMAL & 0.30 & XUHIZ $=>$ XUMAL & 0.04 \\
\hline XUMAL $=>$ XUSIN & 0.07 & XUMAL $\neq>$ XUSIN & 0.94 & XUMAL $\neq>$ XUSIN & 0.60 \\
\hline XUMAL $\neq>$ XUHIZ & 0.47 & XUMAL $\neq>$ XUHIZ & 0.30 & XUMAL $\neq>$ XUHIZ & 0.40 \\
\hline
\end{tabular}




\section{Conclusions}

Over the past decade the world is faced with two devastating crises, 2008 Global Crisis and Greek Debt Crisis. These crises changed too many relations between financial and economic variables. For this reason it is thought that these crises changed the degree and direction of volatility spillovers. In this context, we aimed to analyze the volatility spillovers between the industrial, services and financial sectors of Borsa Istanbul based on the crises and so that to provide information to the investors who are willing to invest in these sectors that they can use in portfolio and risk management processes. We used Hafner and Herwartz causality in variance test for this purpose and results showed that volatility spillovers between BIST sector indexes changed due to 2008 Global Crisis and 2009 Greek Debt Crisis.

The findings reveal that there are reciprocal volatility spillovers between industrial and financial sectors and unidirectional spillover from services to industrial sector before the 2008 Global Crisis. But there is no spillover between the index returns after the Global Crisis indicating that crises change the volatility linkages between sector index returns. It is also determined there are volatility spillovers from industrial sector to services and financial sectors and from services to financial sector.

In this context, it can be said that, investors who construct their portfolios based on BIST sector indexes should follow international events closely and consider the direction of volatility spillovers while diversifying their portfolios. On the other hand, to determine the frequency dimension of relations and to detect the events that cause changes in relations is also important in investment decisions in order to increase efficiency of diversification. Also, for further studies the performance of the portfolios that are created by considering the changing volatility spillovers between sector indexes and therefore, the efficiency of diversification can be analyzed by portfolio performance measurement techniques.

\section{REFERENCES}

[1] H. Yoon, H. Zo and A. P. Ciganek. Does XBRL adoption reduce information asymmetry? Journal of Business Research, Vol.64, 157-163, 2011.

[2] A. Hameed, H. Ashraf. Stock market volatility and weak-form efficiency: Evidence from an emerging market, The Pakistan Development Review, Vol.45, No.5, 1029-1040, 2006.

[3] G. M. Gallo and E, Otranto. Volatility Spillovers, Interdependence and Comovements: A Markov Switching Approach, Computational Statistics \& Data Analysis, Vol. 52, No. 6, 3011-3026, 2007.

[4] A. F. Darrat, O. M. Benkato. Interdependence and volatility spillovers under market liberalization: The case of Istanbul Stock Exchange, Journal of Business Finance \& Accounting,
Vol.30, No.7-8, 1089- 1114, 2003.

[5] F. S. Mishkin. Anatomy of a financial cries. Journal of Evolutionary Economics, Vol. 2, 115-130, 1992.

[6] C. W. J. Granger and P. Newbold. Spurious regressions in econometrics, Journal of Econometrics, Vol. 2, No. 2, 111-120, 1974

[7] A. Dania and J. E. Spillan. Volatility transmission from mature global stock markets to Middle East and North African stock markets, Accounting and Finance Research, Vol. 2, No. 1, 19-31, 2013.

[8] A. M. Khalid and M. Kawai. Was financial market contagion the source of economic crisis in Asia? Evidence using a multivariate VAR model, Journal of Asian Economics, Vol. 14, No. 1, 131-156, 2003.

[9] B. Athanasios and T. Kanellos. Spillover effects among share prices in the Athens' Stock Exchange, Spoudai, Vol. 60, No. 3-4, 69-100, 2010

[10] C. M. Hafner and H. Herwartz. A Lagrange multiplier test for causality in variance, Economics Letters, Vol. 93, No. 1, 137-141, 2006.

[11] D. Dimitriou and T. Simos. Contagion channels of the USA subprime financial crisis, Journal of Financial Economic Policy, Vol. 5. No. 1, 61-71, 2013.

[12] D. Kenourgios, A. Samitas and N. Paltalidis. Financial crises and stock market contagion in a multivariate time-varying asymmetric framework, Journal of International Financial Markets, Institutions \& Money, Vol. 21, No.1, 92-106, 2011.

[13] D. Kenourgios and P. Padhi. Emerging markets and financial crises: Regional, global or isolated shocks?, Journal of Multinational Financial Management, Vol. 22, No. 1-2, 24-38, 2012.

[14] E. K. O and P. I. Ali. The nature of domestic volatility transmission between sectors of the Nigerian economy. ACRN Journal of Finance and Risk Perspectives, Vol 3, No. 3, 92-102, 2014.

[15] J. A.Chan-Lau and I. lvaschenko. Asian flu or Wall Street virus? Price and volatility spillovers of the tech and non-tech sectors in the United States and Asia, IMF WP/02/154, 2002.

[16] J. H. Cho and A. M. Parhizgari. East Asian financial contagion under DCC-GARCH, International Journal of Banking and Finance, Vol. 6, No. 1, 17-30, 2008.

[17] J. Nikkinen, K. Saleem and M. Martikainen. Transmission of the Subprime Crisis: Evidence from industrial and financial sectors of BRIC Countries, Journal of Applied Business Research, Vol. 29, No. 5, 1469-1478, 2013.

[18] K. F. Luchtenberg and Q. V. Vu. The 2008 financial crisis: Stock market contagion and its determinants, Research in International Business and Finance, Vol. 33, 178-203, 2015.

[19] K. Ranjeeni. Sectoral and industrial performance during a stock market crisis, Economic Systems, Vol. 38, No.2, 178-193, 2014.

[20] L. S. Junior and I. D. P. Franca. Correlation of financial markets in times of crisis, Physical A, Vol. 391, No. 1-2, 187-208, 2012.

[21] L. Wang. Who moves East Asian stock markets? The role of 
the 2007-2009 global financial crisis, Journal of International Financial Markets, Institutions \& Money, Vol. 28, 182-203, 2014.

[22] M. Dungey and D. Gajurel. Equity market contagion during the global financial crisis: Evidence from the world's eighth largest economies, Economic Systems, Vol. 38, No. 2, 161-177, 2014.

[23] M. Taşdemir and M. Aslan. Uncertainty Spillovers between Exchange Rates and Inflation: Evidence from Turkey, Anadolu International Conference in Economics. Eskișehir: Anadolu Üniversitesi, 2009.

[24] M. Okur and E. Çevik. Testing intraday volatility spillovers in Turkish capital markets: Evidence from ISE, Economic Reserach, Vol. 26, No. 3, 99-116, 2013.

[25] N. A. Görmüş. Causality and volatility spillover effects on sub-sector energy portfolios, Doctoral Thesis, Texas: The University of Texas at Arlington, 2012.

[26] S. A. Hassan and F. Malik. Multivariate GARCH modeling of sector volatility transmission, The Quarterly Review of Economics and Finance, Vol. 47, No. 3, 470-480, 2007.

[27] S. D. Bekiros, Contagion, decoupling and the spillover effects of the US financial crisis: Evidence from the BRIC markets, International Review of Financial Analysis, Vol. 33, No. 58-69, 2014.

[28] S. D. Köseoğlu and E. I. Çevik. Testing for causality in mean and variance between the stock market and the foreign exchange market: An application to the major central and eastern European countries, Czech Journal of Economics and Finance, Vol. 63, No. 1, 65-86, 2013.

[29] S. M Hammoudeh, Y. Yuan and M. McAleer. Shock and volatility spillovers among equity sectors of the Gulf Arab stock markets, The Quarterly Review of Economics and Finance, Vol. 49, No. 1, 829-842, 2009.

[30] S. Nazlıŏlu, C. Erdem and U. Soytaş. Volatility spillover between oil and agricultural commodity markets, Energy Economics, Vol. 36, 658-665, 2013.

\footnotetext{
i Earlier version of this study was presented in 32nd International Business
} Research Conference, Melbourne, Australia, 23 - 25 November, 2015.
[31] S. Nazlığlu, S. Hammoudeh and R. Gupta. Volatility transmission between Islamic and conventional equity markets: Evidence from causality-in-variance test, Applied Economics, Vol. 47, No. 46, 4996-5011, 2015.

[32] S. Neaime. Volatilities in Emerging MENA Stock Markets, Thunderbird International Business Review, Vol. 48, No. 4, 455-484, 2006.

[33] S. Y. Yang. A DCC analysis of international stock market correlations: the role of Japan on the Asian Four Tigers, Applied Financial Economics Letters, Vol. 1, No. 2, 89-93, 2005.

[34] T. Korkmaz and E. İ. Çevik. Reel Kesim Güven Endeksi ile İMKB 100 Endeksi arasındaki dinamik nedensellik ilişkisi, İstanbul Üniversitesi İşletme Fakültesi Dergisi, Vol. 38, No.1, 24-37, 2009.

[35] T. Moore. The volatility spillover from the market to disaggregated industry stocks: The case for the US and UK, International Journal of Business and Economics, Vol. 10, No. $1,61-68,2011$

[36] T. Syriopoulos, B. Makram and A. Boubaker. Stock market volatility spillovers and portfolio hedging: BRICS and the financial crisis, International Review of Financial Analysis, Vol. 39, 7-18, 2015.

[37] U. Adıgüzel, T. Bayat, S. Kayhan and Ş. Nazlığlu. Oil prices and exchange rates in Brazil, India and Turkey: Time and frequency domain causality analysis, Siyaset, Ekonomi ve Yönetim Araştırmaları Dergisi, Vol. 1, No. 1, 49-73, 2013.

[38] V. T. Alaganar and R. Bahr. An international study of causality-in-variance: Interest rate and financial returns, Journal of Economics and Finance, Vol. 27, No. 1, 39-55, 2003.

[39] Y. Hong. A test for volatility spillover with application to exchange rates, Journal of Econometrics, Vol. 103, No. 1-2, 183-224, 2001.

[40] Y. W. Cheung and L. K. Ng. A causality in variance test and its application to financial market prices, Journal of Econometrics, Vol. 72, No. 33-48, 1996. 